\title{
THE LEVEL OF INTEREST AND INFORMATION LITERACY OF STUDENTS OF THE MAKASSAR TOURISM POLYTECHNIC IN LEARNING ISLAM
}

\author{
Saenal Abidin ${ }^{1}$ \\ Alauddin State Islamic University of Makassar ${ }^{1}$ \\ saenal.abidin@uin-alauddin.ac.id ${ }^{1}$
}

\begin{abstract}
This study focused on the level of interest and information literacy of students in learning Islam, particularly at the Makassar Tourism Polytechnic campus. According to the researcher, it is necessary to research this issue to find out the extent of the information literacy skills and interest of the students of Tourism Polytechnic in improving their knowledge of Islam and the extent of their readiness to apply the knowledge they obtain in society. This study used a descriptive method with a quantitative approach. Data were collected using a questionnaire by employing a Likert scale. The results showed that the average students' interest in learning Islam was $65.25 \%$ or categorized in the high level However, this figure had not yet reached a very high level. Therefore, motivation and more effective and fun teaching methods for students are needed to improve their interests. Meanwhile, the average level of media literacy skills was 79.38 or categorized in the high level. On average, they had been able to use information media as a learning resource independently. They had implemented part of the information literacy model, which was the identification of needs before searching. Regarding the literature they chose to access to information, they tended to prefer instant access to information, which was the internet. Meanwhile, interest in printed books was very low. Therefore, they require a good understanding and education on how to trace valid information through various relevant information media.
\end{abstract}

Keywords: Interests; Literacy; Information Media; Learning

\section{INTRODUCTION}

According to UNESCO, information literacy is the ability to realize information needs when information is required, identify and locate the required information, evaluate information critically, organize and integrate information into existing knowledge, and effectively, legally and ethically use and communicate the information. ${ }^{1}$ The discussion in this study focused on media literacy as a constituent of information literacy. Media literacy is the capability to access, analyze, evaluate, and communicate information in a range of forms of media. It is a set of perspectives that are actively utilized when accessing the mass media to interpret the messages available. Media literacy aims to make the audiences understand and know the content of the media, media effects, and the media industry. It can prevent someone from believing in hoaxes. Hoaxes are information that is falsified to cover up real information. Alternatively stated, hoaxes can also be interpreted as an attempt to distort facts utilizing information that looks convincing but

\footnotetext{
${ }^{1}$ UNESCO, "Global Media and Information Literacy Assessment Framework: Country Readiness and Competences," United Nations Educational, Scientific and Cultural Organization (UNESCO), 2013.
} 
cannot be verified. ${ }^{2}$ Improving media literacy skills also makes a person better understand themselves by selecting appropriate information to be used for them. By employing media literacy skills, a person can be benefited from all the potential of the available media to improve the ability to read situations and all the existing opportunities for selfdevelopment. Furthermore, the order to develop literacy is an obligation in Islam as can be seen in the QS. al-Alaq: 1-5

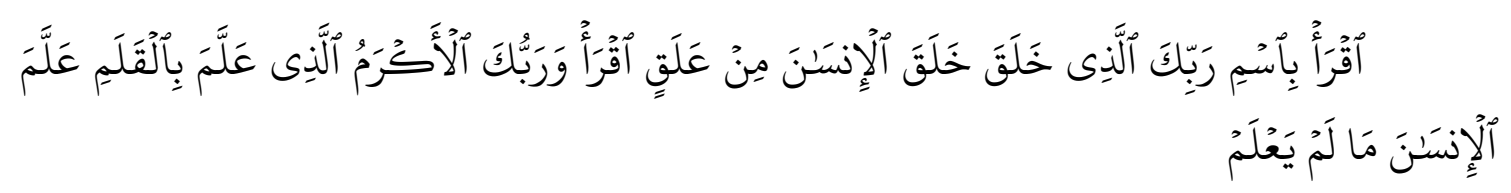

Translation:

"Read, O Prophet, in the Name of your Lord Who created humans from a clinging clot. Read! And your Lord is the Most Generous, who taught by the pen, taught humanity what they knew not."3

The verse above describes the significance of reading, understanding, identifying, and learning something wisely, including in examining and using the media as an attempt to develop information literacy. Surah al-Alaq verses one to five is the first verses revealed by Allah Swt. to Rasulullah SAW containing the order to read. The word 1 i in an order word meaning "read!". In the past, the meaning of reading was limited to the ability to spell the letters into a word. However, at present, with the development of science and technology in information media, the meaning of the word literacy can be developed as an order to "be literate!". It is then followed with the order to chant or remember the name of Allah; thus, the following verses fundamentally invite people to realize the significance of learning and improve their insight so that they can understand the greatness of Allah and bring happiness to them. Therefore, the word "iqra" in the context of this study is interpreted by the writer as "literacy". Moreover, the discussion would be specified as information media literacy, indicating the ability to properly utilize information media as a medium of learning in establishing Islamic religious insights.

With literacy skills, a person will be able to know Allah and distinguish between good and bad and haq and vanity. Regarding the importance of literacy, Allah Swt. said in QS. Ar-Rad verse 16:

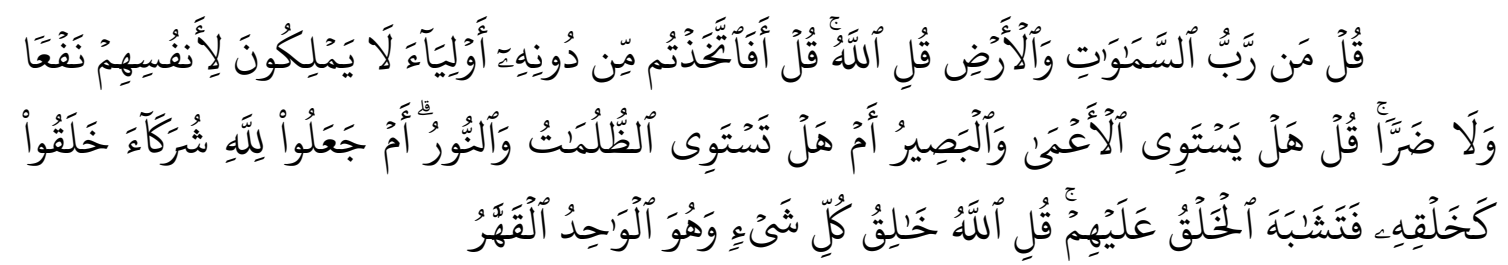

Translation:

"Ask them, O Prophet, "Who is the Lord of the heavens and the earth?" Say, "Allah!" Ask them, "Why then have you taken besides Him lords who cannot even benefit or protect themselves?" Say, "Can the blind and the sighted be equal? Or can darkness and light be equal?" Or have they associated with Allah partners who supposedly produced a

2 Gumilar Gumgum, Adiprasetio Justito, and Maharani Nunik, "Literasi Media: Cerdas Menggunakan Media Sosial Dalam Menanggulangi Berita Palsu (Hoax) Oleh Siswa Sma," Pengabdian Kepada Masyarakat, 2017, https://doi.org/1410 - 5675.

${ }^{3}$ RI Kementerian Agama, Al-Qur'an Terjemahan, Al-Qur'an Terjemahan, 2007. 


\section{The Level of Interest and Information Literacy of Students of The Makassar Tourism Polytechnic in Learning Islam}

creation like His, leaving them confused between the two creations? Say, "Allah is the Creator of all things, and $\mathrm{He}$ is the One, the Supreme".

Based on the verse above, the advantage of literacy is that humans can distinguish between good and bad things. In tracing information media, techniques and ethics are necessary to be considered so that people will not get lost in tracing information due to a large amount of information that cannot be accounted for its validity or commonly referred to as hoaxes.

In developing scientific insights into a certain discipline, it is important to have the ability to access information through various information media properly. Another aspect that can support the development of scientific insights is an individual's interest in something, including in the case of learning Islamic education. This study focused on the level of information literacy and students' interest in learning Islam, particularly at the Makassar Tourism Polytechnic campus. According to the researcher, it is necessary to research this issue to find out the extent of the information literacy skills and interest of the students of Tourism Polytechnic in improving their knowledge of Islam and the extent of their readiness to apply the knowledge they obtain in society. Learning Islam is a provision for students of tourism polytechnic in performing the tourism profession. Islamic values should be firmly rooted in them so that the values become a control in providing the best service as prospective professional tourism.

The results of this study would provide a general description of the phenomena occurring in many universities in Indonesia and particularly at the Makassar Tourism Polytechnic campus.

\section{THEORETICAL REVIEW}

A previous study that has a substantial relationship with this study was conducted by Kurniawati in 2016 in a survey on digital media literacy of students of Muhammadiyah University of Bengkulu. The results of the study revealed that: 1). Understanding of the students of Muhammadiyah University of Bengkulu of digital media was at the medium category, 2). The individual level of competence of the students of the Muhammadiyah University of Bengkulu in digital media literacy was at the basic level, 3). The factors affecting the individual level of competence related to digital media literacy were mainly the factor of a family environment. ${ }^{5}$

Another study was conducted by Wahidin entitled the Implementation of Media Literacy in the Learning Process of Islamic Education and Character. The results showed that many forms of instructional media could be utilized in the PAI learning process. The utilization of learning media in the learning process is not a goal but as a tool and a source of learning for students. Therefore, in its implementation, media literacy of Islamic Education teachers and Character teachers towards various forms of learning media are required. In addition, the ways, uses, functions and objectives of their use are needed to understand. ${ }^{6}$

\footnotetext{
${ }^{4}$ RI Kementerian Agama.

5 J. Kurniawati and S. Baroroh, "Literasi Media Digital Mahasiswa Universitas Muhammadiyah Bengkulu,” Jurnal Komunikator, 2016.

${ }^{6}$ Unang Wahidin, "Implementasi Literasi Media Dalam Proses Pembelajaran Pendidikan Agama Islam Dan Budi Pekerti," Edukasi Islami: Jurnal Pendidikan Islam 7, no. 02 (2018), https://doi.org/10.30868/ei.v7i2.284.
} 
This study had differences from previous studies. It was more focused on the percentage of information media literacy and students' interest in learning Islam. It was carried out to determine the level of information media literacy skills of students and the extent of the percentage of their interest in learning Islam. The results of this study are expected to enrich scientific knowledge by understanding interest and media literacy. Therefore, it becomes a reference in directing students to explore information independently to improve their Islamic insight.

Information media is a set of instruments that assist a person in the retrieval of information using media literacy skills in its utilization. ${ }^{7}$ Meanwhile, media literacy is often translated directly as 'media literate'. This kind of perspective is considered to simplify the challenge of developing media literacy capacity because if it is analogized to 'literate', then media literacy can be interpreted as 'merely' not media blind. The very fast development of the media, particularly the mass media, must be balanced with a comprehensive media literacy movement so that the majority of the public can be benefited from the mass media for the progress and welfare of the nation. Through the development of media literacy studies, it is expected that the public will be able to distinguish between useful and harmful media content that causes mudharat or loss to their lives. ${ }^{8}$

Globalization results in a borderless world in which information can be broadly spread without any filters that mix up hoaxes or fake information. In determining diverse information needs in the digital era, people are expected to be more selective, sensitive, and think critically regarding information that is randomly disseminated in the digital world. Literacy is a capability to supports the information civilization of the people who are living in an all-technological era at present. It is the ability to identify, analyze, and evaluate information and media in finding appropriate, accurate, credible and up-to-date information or content. The ability to understand, access, analyze, evaluate and communicate information in the form of media content is an aspect that is necessary to be owned so that they will not be misguided by hoaxes that flow from messages that disseminate in mass and digital media.

In essence, the media does not only provide information and entertainment but also asks the public to represent messages recorded by readers. The basic principles of messages conveyed by the media are stated by the Association for Media Literacy (2007) that media messages are produced with a purpose; media messages have the characteristics, power, and uniqueness of constructing different languages; and humans utilize their abilities, beliefs, experiences to construct meanings conveyed by (representative) media. Information literacy becomes a solution against information circulating in digital media with the ability to think critically in analyzing and evaluating information at hand. ${ }^{9}$

\footnotetext{
${ }^{7}$ Saenal Abidin, Teknologi Media Informasi (Gowa: Gunadarma Ilmu, 2018).

${ }^{8}$ Vibriza Juliswara, "Mengembangkan Model Literasi Media Yang Berkebhinnekaan Dalam Menganalisis Informasi Berita Palsu (Hoax) Di Media Sosial," Jurnal Pemikiran Sosiologi 4, no. 2 (2017), https://doi.org/10.22146/jps.v4i2.28586.

9 Pranindya Purwaningtiyas, "Literasi Informasi Dan Literasi Media," IQRA': Jurnal Ilmu Perpustakaan Dan Informasi (e-Journal), 2019, https://doi.org/10.30829/iqra.v12i2.3978.
} 


\section{RESEARCH METHODOLOGY}

This study was descriptive research with a quantitative approach. This study was conducted by distributing questionnaires by employing a Likert scale to 117 online respondents using the Google form. The distribution of the questionnaire was done directly through the WhatsApp Group (WAG) that was made previously by including all potential respondents and ensuring that they were students of the Makassar Tourism Polytechnic and learning Islamic education. The WhatsApp contact data of the students were obtained from the academic section of the Makassar Tourism Polytechnic.

The percentage score was based on the respondents' choice of answers which were then calculated as research data. The research was conducted at the Makassar Tourism Polytechnic campus on four classes of four study programs consisting of 27 students of UPW1A (Travel Agent Business) study program, 31 students of MJP1B (Travel Agent Business Management) study program, 31 students of PPH1B (Hospitality Management) study program, 28 students of DPA1B (Tourism Destinations) study program. The total research population was 117 people. Based on the statement expressed by Sugiyono, the sample is taken if the population is large and it is impossible for the researcher to study everything in the population. ${ }^{10}$ Because the population is not that large, the researcher took all the population as the research object. Therefore, this study was population research.

In making decisions, the writer refered to the theory stated by Darmadi on the interval scale as follows:
1. $0 \%-19,99 \%$
: Very Low
2. $20 \%-39,99 \%$
: Low
3. $40 \%-59,99 \%$
: Moderate
4. $60 \%-79,99 \%$
: High
5. $80 \%-100 \%$
: Very High ${ }^{11}$

\section{RESEARCH RESULTS}

This study aimed to find out the extent of the percentage level of information media literacy of students and their interest in learning Islam. Based on the answers of 117 respondents to several statement items, the elaboration of the research results is as follows:

\section{A. Students' interest in learning Islam}

1. Like learning Islam and have high motivation to learn

\begin{tabular}{|c|c|c|c|}
\hline Category & Score & Frequency & Percentage \\
\hline Like it very much & 5 & 102 & $87 \%$ \\
\hline Like it & 4 & 12 & $10 \%$ \\
\hline Uncertain & 3 & 3 & $3 \%$ \\
\hline Do not like it much & 2 & - & $0 \%$ \\
\hline Do not like it & 1 & - & $0 \%$ \\
\hline \multicolumn{2}{|c|}{ Total } & $\mathbf{1 1 7}$ & $\mathbf{1 0 0 \%}$ \\
\hline
\end{tabular}

10 Sugiyono, Metode Penelitian Pendidikan: Pendekatan Kuantitatif, Kualitatif Dan R\&D (Bandung: Alfabeta, 2012).

${ }^{11}$ Hamid Darmadi, Metode Penelitian Pendidikan Dan Sosial, Metode Penelitian Pendidikan Dan Sosial, 2013. 
Of the 117 students, 87 percent really liked learning Islam, 10 percent said they liked it, and 3 percent said that they still could not make a conclusion. Based on these results, it can be seen that approximately, many students (87\%) really like learning Islam. It can be concluded that they like learning Islam because of several factors, including the teaching techniques of lecturers, their awareness of the significance of learning Islam, and the availability of learning materials for them.

2. Ease of processing Islamic education lessons

\begin{tabular}{|c|c|c|c|}
\hline Category & Score & Frequency & Percentage \\
\hline Very easy & 5 & 80 & $68 \%$ \\
\hline Easy & 4 & 32 & $28 \%$ \\
\hline Uncertain & 3 & - & $0 \%$ \\
\hline Difficult & 2 & 5 & $4 \%$ \\
\hline Very difficult & 1 & - & $0 \%$ \\
\hline \multicolumn{2}{|c|}{ Total } & $\mathbf{1 1 7}$ & $\mathbf{1 0 0 \%}$ \\
\hline
\end{tabular}

Of the 117 students, 68 percent were very easy to process Islamic lessons, 28 percent said it was easy, and only 4 percent admitted that it was difficult to process Islamic learning.

3. Enjoy learning by searching Islamic references on the Internet

\begin{tabular}{|c|c|c|c|}
\hline Category & Score & Frequency & Percentage \\
\hline Very enjoy & 5 & 42 & $36 \%$ \\
\hline Enjoy & 4 & 68 & $58 \%$ \\
\hline Uncertain & 3 & 5 & $4 \%$ \\
\hline Do not enjoy & 2 & 2 & $2 \%$ \\
\hline Really not enjoy & 1 & - & - \\
\hline \multicolumn{2}{|c|}{ Total } & $\mathbf{1 1 7}$ & $\mathbf{1 0 0 \%}$ \\
\hline
\end{tabular}

Of the 117 students, 36 percent very enjoyed searching references on the internet regarding Islamic lessons, 58 percent said they enjoyed, 4 percent had not been able to make conclusions, and 2 percent said they did not enjoy searching references on the internet because of a particular reason.

4. Enjoy learning Islamic learning materials independently by searching learning literature from various sources

\begin{tabular}{|c|c|c|c|}
\hline Category & Score & Frequency & Percentage \\
\hline Very enjoy & 5 & 21 & $18 \%$ \\
\hline Enjoy & 4 & 73 & $62 \%$ \\
\hline Uncertain & 3 & 23 & $20 \%$ \\
\hline Do not enjoy & 2 & - & - \\
\hline Really not enjoy & 1 & - & - \\
\hline \multicolumn{2}{|c|}{ Total } & $\mathbf{1 1 7}$ & $\mathbf{1 0 0 \%}$ \\
\hline
\end{tabular}

Of the 117 students, 18 percent very enjoyed browsing literature on learning Islam independently, 62 percent said they enjoyed it, and 20 percent were still in doubt in making choices.

Based on the descriptions in the several tables above, it can be observed that the dominant numbers were in the very interested category. If calculated approximately using the interval formula, the score obtained was at $65.25 \%$. Therefore, it can be concluded that the level of students' interest in learning Islam based on the interval scale was in the 
score range category of $60 \%-79.99 \%$, indicating that students' interest was in the high category.

\section{B. Information Media Literacy of Students of Makassar Tourism Polytechnic}

1. Identify information needs before conducting a search

\begin{tabular}{|c|c|c|c|}
\hline Category & Score & Frequency & Percentage \\
\hline Must do it & 5 & 49 & $42 \%$ \\
\hline Always do it & 4 & 42 & $36 \%$ \\
\hline Sometimes do it & 3 & 26 & $22 \%$ \\
\hline Ever did it & 2 & - & - \\
\hline Never did it at all & 1 & - & - \\
\hline \multicolumn{2}{|c|}{ Total } & $\mathbf{1 1 7}$ & $\mathbf{1 0 0 \%}$ \\
\hline
\end{tabular}

Of the 117 students, 42 percent would first identify their information needs before search for information each time, in order not to make the wrong choice of information. It becomes the basis of an information literacy skill. 36 percent always do it, and 22 percent only do it sometimes. However, the most important thing is that all respondents understand the importance of identifying their needs before making a decision.

2. Proficient in using information media technology devices

\begin{tabular}{|c|c|c|c|}
\hline Category & Score & Frequency & Percentage \\
\hline Very proficient & 5 & 28 & $24 \%$ \\
\hline Proficient & 4 & 77 & $66 \%$ \\
\hline Uncertain & 3 & 9 & $8 \%$ \\
\hline Not Proficient & 2 & 3 & $2 \%$ \\
\hline Really Not Proficient & 1 & - & - \\
\hline \multicolumn{2}{|c|}{ Total } & $\mathbf{1 1 7}$ & $\mathbf{1 0 0 \%}$ \\
\hline
\end{tabular}

Of the 117 students, 24 percent were very proficient in using information media technology devices, 66 percent said that they were proficient, 8 percent were still in doubt in making choices, and 2 percent claimed to be not proficient.

3. Diligently searching for material related to Islam through information media technology

\begin{tabular}{|c|c|c|c|}
\hline Category & Score & Frequency & Percentage \\
\hline Very Diligent & 5 & 43 & $36 \%$ \\
\hline Diligent & 4 & 69 & $58 \%$ \\
\hline Uncertain & 3 & 5 & $4 \%$ \\
\hline Not Diligent & 2 & - & $2 \%$ \\
\hline Really Not Diligent & 1 & - & $0 \%$ \\
\hline \multicolumn{2}{|c|}{ Total } & $\mathbf{1 1 7}$ & $\mathbf{1 0 0 \%}$ \\
\hline
\end{tabular}

Of the 117 students, 36 percent were very diligent in searching for material related to Islam through information technology devices, 58 percent said they were diligent, 4 percent were still hesitant in making choices, and only 2 percent were not diligent in searching for material related to Islam through information media technology.

4. Like to search for information through printed books

\begin{tabular}{|c|c|c|c|}
\hline Category & Score & Frequency & Percentage \\
\hline Like it very much & 5 & 9 & $8 \%$ \\
\hline
\end{tabular}




\begin{tabular}{|c|c|c|c|}
\hline Like it & 4 & 26 & $22 \%$ \\
\hline Uncertain & 3 & 32 & $27 \%$ \\
\hline Do not like it much & 2 & 50 & $43 \%$ \\
\hline Do not like it & 1 & - & $0 \%$ \\
\hline \multicolumn{2}{|c|}{ Total } & $\mathbf{1 1 7}$ & $\mathbf{1 0 0 \%}$ \\
\hline
\end{tabular}

Of the 117 students, only 8 percent really like to use printed books to find information related to Islam, 22 percent said they liked it, 32 percent were still hesitant about making choices, and the interesting point is that 50 percent said they did not like to search for information on printed books. It indicates that approximately, students are more likely to use internet media technology to search for information due to the ease of access and efficiency of the time it takes.

5. Internet media Like Google, Youtube, and Social media are routinely used to learn and share Islamic insights

\begin{tabular}{|c|c|c|c|}
\hline Category & Score & Frequency & Percentage \\
\hline Very Routine & 5 & 55 & $47 \%$ \\
\hline Routine & 4 & 62 & $53 \%$ \\
\hline Uncertain & 3 & - & $0 \%$ \\
\hline Not Routine & 2 & - & $0 \%$ \\
\hline Really Not Routine & 1 & - & $0 \%$ \\
\hline \multicolumn{2}{|c|}{ Total } & $\mathbf{1 1 7}$ & $\mathbf{1 0 0 \%}$ \\
\hline
\end{tabular}

Of the 117 students, 47 percent very routinely shared and learned via YouTube, Google, and social media about Islamic insights, and 53 percent said they routinely did it and none of them said no. It indicates that it is true that students really like to use internet technology compared to printed media.

6. In searching for the information needed, it is always fast and accurate

\begin{tabular}{|c|c|c|c|}
\hline Category & Score & Frequency & Percentage \\
\hline Very Fast & 5 & 23 & $20 \%$ \\
\hline Fast & 4 & 71 & $60 \%$ \\
\hline Uncertain & 3 & 14 & $12 \%$ \\
\hline Slow & 2 & 9 & $8 \%$ \\
\hline Very Slow & 1 & - & $0 \%$ \\
\hline \multicolumn{2}{|c|}{ Total } & $\mathbf{1 1 7}$ & $\mathbf{1 0 0 \%}$ \\
\hline
\end{tabular}

Of the 117 students, 20 percent said they were very fast when searching for information related to Islam, 60 percent said they were fast in doing it, 12 percent were still in doubt, and 8 percent said they were still slow in finding information.

7. Readiness to answer all the challenges of life with Islamic insight.

\begin{tabular}{|c|c|c|c|}
\hline Category & Score & Frequency & Percentage \\
\hline Very Sure & 5 & 14 & $12 \%$ \\
\hline Sure & 4 & 79 & $68 \%$ \\
\hline Uncertain & 3 & 12 & $10 \%$ \\
\hline Not Really Sure & 2 & 12 & $10 \%$ \\
\hline Not Sure & 1 & - & $0 \%$ \\
\hline \multicolumn{2}{|c|}{ Total } & $\mathbf{1 1 7}$ & $\mathbf{1 0 0 \%}$ \\
\hline
\end{tabular}

Of the 117 students, only 12 percent were very confident about being able to answer all the challenges of life with the knowledge of Islam that they have, and 68 


\section{The Level of Interest and Information Literacy of Students of The Makassar Tourism Polytechnic in Learning Islam}

percent said that they were sure. It shows a positive result because belief is an essential aspect in achieving success. Confidence becomes an extraordinary suggestion that can provide an injection of motivation for self-development, including literacy skills. However, it turns out that 10 percent were still doubtful and even 10 percent were not sure. It only requires encouragement and the participation of lecturers in motivating students, particularly the participation of their parents or those closest to them.

Based on the descriptions in the several tables above, it can be observed that the dominant numbers were in the very high category. If calculated approximately using the interval formula, the score obtained was at $79.38 \%$. Therefore, it can be concluded that the level of students' information media literacy towards Islamic learning based on the interval scale was in the score range category of $60 \%-79.99 \%$, indicating that students' media literacy was in the high category.

\section{CONCLUSIONS AND IMPLICATIONS}

The results showed that the level of interest of the students of Makassar Tourism Polytechnic towards religious learning was at $65.25 \%$. Therefore, it can be concluded that the level of students' interest in learning Islam based on the interval scale was in the score range category of $60 \%-79.99 \%$, indicating that the students' interest was in the "high/interested" category. It proves that students had realized the significance of learning Islam. However, the numbers obtained were not optimum because they had not yet reached a very high score. Therefore, it needs strong encouragement and motivation to optimize their interest to the "very high/very interested" level. If observed from the basis of their formal Islamic education, this figure is highly reasonable because of the 117 recipients, only $6 \%$ came from madrasah and Islamic boarding schools, while $94 \%$ came from public schools. Approximately, students were still trying to get to know, deepen, and love Islamic learning.

Based on the explanation of the research results, it can be observed that the dominant numbers were in the very high category. If calculated approximately using the interval formula, the score obtained was at $79.38 \%$. Therefore, it can be concluded that the level of students' information media literacy towards Islamic learning based on the interval scale was in the score range category of $60 \%-79.99 \%$, indicating that students' media literacy was in the high category. On average, they had been able to use information media as a learning resource independently. They had implemented part of the information literacy model, which was the identification of needs before searching. Regarding the literature they chose to access to information, they tended to prefer instant access to information, which was the internet. Meanwhile, interest in printed books was very low. Therefore, they require a good understanding and education on how to trace valid information through various relevant information media.

When seen from their confidence and readiness to apply the knowledge they have gained, on average, they had expressed confidence of approximately $68 \%$. However, some of them were still doubtful and some were even less sure of themselves. However, the essential aspect is that their motivation to learn was already in the range of $87 \%$, which becomes a crucial asset in a learning process.

This study was a description of the phenomena occurring in universities, particularly at the Makassar Tourism Polytechnic and a general description of the learning of Islam in any university. Therefore, the results of this study are expected to be a reference in determining teaching methods, particularly in Islamic learning at the 
university level, emphasizing that students' interest and information literacy, particularly in learning Islam, are more likely to use information technology media than printed media. In addition, in learning, they still need guidance in searching for appropriate information. In this case, obviously, qualified information literacy from lecturers related to Islamic education courses is needed.

\section{REFERENCE}

Abidin, Saenal. Teknologi Media Informasi. Gowa: Gunadarma Ilmu, 2018.

Gumgum, Gumilar, Adiprasetio Justito, and Maharani Nunik. "Literasi Media: Cerdas Menggunakan Media Sosial Dalam Menanggulangi Berita Palsu (Hoax) Oleh Siswa Sma." Pengabdian Kepada Masyarakat, 2017. https://doi.org/1410 - 5675.

Hamid Darmadi. Metode Penelitian Pendidikan Dan Sosial. Metode Penelitian Pendidikan Dan Sosial, 2013.

Juliswara, Vibriza. "Mengembangkan Model Literasi Media Yang Berkebhinnekaan Dalam Menganalisis Informasi Berita Palsu (Hoax) Di Media Sosial." Jurnal Pemikiran Sosiologi 4, no. 2 (2017). https://doi.org/10.22146/jps.v4i2.28586.

Kementerian Agama, RI. Al-Qur'an Terjemahan. Al-Qur'an Terjemahan, 2007.

Kurniawati, J., and S. Baroroh. "Literasi Media Digital Mahasiswa Universitas Muhammadiyah Bengkulu.” Jurnal Komunikator, 2016.

Purwaningtiyas, Pranindya. "Literasi Informasi Dan Literasi Media." IQRA : Jurnal Ilmu $\begin{array}{llll}\text { Perpustakaan Dan Informasi } 2019 . & \text { (e-Journal), }\end{array}$ https://doi.org/10.30829/iqra.v12i2.3978.

Sugiyono. Metode Penelitian Pendidikan : Pendekatan Kuantitatif, Kualitatif Dan R\&D. Bandung: Alfabeta, 2012.

UNESCO. "Global Media and Information Literacy Assessment Framework: Country Readiness and Competences." United Nations Educational, Scientific and Cultural Organization (UNESCO), 2013.

Wahidin, Unang. "Implementasi Literasi Media Dalam Proses Pembelajaran Pendidikan Agama Islam Dan Budi Pekerti." Edukasi Islami : Jurnal Pendidikan Islam 7, no. 02 (2018). https://doi.org/10.30868/ei.v7i2.284. 